Tér és Társadalom 22. évf. 2008/2. 1-20. p.

\title{
A REGIONÁLIS VERSENYKÉPESSÉG ÉS A TERÜLETI KÜLÖNBSÉGEK KÖLCSÖNHATÁSAI
}

\author{
(Interactions between Regional Competitiveness and Territorial \\ Disparities)
}

\section{FENYÖVÁRI ZSOLT - LUKOVICS MIKLÓS}

Kulcsszavak:

regionális versenyképesség területi különbségek elméleti közgazdaságtani irányzatok elméleti régiótípusok

Napjaink egyik legfontosabb kihivása a globális versenyben való helytállás. Részben ennek hatására egyre szélesebb körben válik elfogadottá, hogy nemcsak a vállalatok, hanem a területi egységek is versenyeznek egymással. Ezen felismerésnek köszönhetöen a terïleti versenyben való helytállást kifejezö regionális versenyképesség fogalma mára a regionális tudomány egyik központi fogalmává vált. Nemcsak a témakör elméleti kérdéseivel foglalkozó kutatók, hanem a gazdaságpolitikusok egy része is a versenyképesség, mint "hivószó" köré szövik programjaikat. Többek között az Európai Unióban a harmonikus, kiegyensúlyozott terïleti fejlödés megvalósitását (vagyis a területi különbségek mérséklését) célzó regionális politika évek óta a régiók versenyképességének javitását tartja a kohézió és a felzárkóztatás egyik legfontosabb, leghatékonyabb eszközének. Habár a terïleti verseny és a regionális versenyképesség a kutatások elöterében áll, ennek ellenére a fogalomkör még napjainkban is viták tárgyát képezí, a különféle elméleti alapokon álló irányzatok képviselöi eltérö módon közelitenek a kérdéskörhöz.

Tanulmányunk célja, hogy áttekintse és szintetizálja az alapvetó elméleti közgazdaságtani irányzatoknak a területi különbségek mérséklödésével, a területi versennyel, a regionális versenyképességgel, valamint az egyes elméleti régiótipusokkal kapcsolatba hozható legfontosabb elképzeléseit. A különféle közgazdaságtani háttérre támaszkodva a regionális tudományon belül is más-más hipotézisek fogalmazódnak meg, és igy a különbözö feltételekkel bíró, eltérö fejlettségü régiók gazdasági felzárkózásáról is különbözö következtetések látnak napvilágot. Vélekedésünk szerint ezúttal is érvényesül a regionális tudomány interdiszciplináris jellegéböl fakadó azon jelenség, hogy az eltérö elméleti alapok és modellfeltételek mentén különbözö következtetésekre jutó gazdasági elméletek nem tudományunk hitelességét kérdöjelezik meg, sokkal inkább annak sokoldalúságára, problémaérzékenységére hivják fel a figyelmet.

\section{Területi különbségek mérséklödése: komparativ és kompetitív elönyök}

A területi különbségek mérése, a kiváltó okok és az okozatok elemzése szinte kezdetek óta a regionális tudomány egyik legfontosabb kérdésköre (Enyedi 1996; Benko 1999; Nemes Nagy 2001; 2005; Lengyel-Rechnitzer 2004). A területi verseny, illetve a regionális versenyképesség kutatása már jóval rövidebb időszakra tekint vissza, habár a közelmúltban megjelentek eltérő fogalmi megközelítéseirỏl igen alapos, a témakơrt körbejáró munkák (Lengyel 2003; Gardiner et al 2004; Horváth 2006), de ennek ellenére ez a kérdéskör még a tudományos viták kereszttüzében áll. A széles körben elfogadható álláspontok kidolgozásához további alapos tudományos kutatásokra, a fogalmak és az eddigi eredmények pontosítására van szủkség. 
A területi különbségek csökkentése az Európai Unió regionális politikájának egyik legfontosabb célja: „a Közösségnek különösen törekednie kell arra, hogy a különbözö fejlettségü térségek közötti különbségeket csökkentse, és a legkevésbé fejlett régiók, szigetek elmaradottságát mérsékelje, beleértve a vidéki területeket is" (EC 1997, 158. cikkely). A 12 új tagállammal történő bővülés után a régiók közötti különbségek megnöttek, részben ebböl adódóan a negyedik kohéziós jelentés kiemelt figyelmet szentel az Európai Unió egyes régiói között kimutatható jelentős területi különbségeknek (EC 2007). A 2007-13 közötti idöszakban a régiók közötti különbségek mérséklésére irányuló irányelvek a versenyképesség javítását emelik ki, összhangban a gazdasági növekedéssel és a foglalkoztatottsággal (EC 2006).

A területi különbségek alakulásáról, tartalmi kérdéseiről és ehhez kapcsolódva a regionális versenyképességről folyó vitákban a felfogások markáns elkülönülése érhető tetten. Alapkérdés, hogy egy gazdaságban a területi különbségek mérséklödéséhez elegendök-e a piaci automatizmusok, tehát előbb-utóbb bekövetkezik-e mindegyik piacgazdaságban a területi kiegyenlítódés? Avagy a piaci folyamatok, a „láthatatlan kéz" ezt nem garantálja és szükség van külső beavatkozásra? Ezen kérdéssel szorosan összefüggésbe hozható az a dilemma, hogy értelmezhetö-e egyáltalán a közgazdaságtan egyik legfontosabb fogalma, a verseny területi egységekre, avagy nem? Ha nem értelmezhetö, akkor nyilván nem beszélhetünk a területi egységek versenyképességéről sem. Ha viszont elfogadjuk a területi verseny létezését, akkor újabb kérdések merülnek fel, pl. mit értünk területi verseny alatt, melyek a fóbb jellemzői? Mindegyik területi egység részt vesz-e a területi versenyben, vagy csak a nagyobb városokkal bíró régiók? Mihez viszonyítsuk a „győztes pozíciót", a többi régió helyzetéhez, vagy az adott régió múltbeli állapotához? Szükségszerü-e, hogy a területi versenyben a gyöztesek mellett vesztesek is legyenek, vagy elképzelhetö, hogy egyidejüleg mindegyik régió győztes lehet? Továbbá, ha mindenki győztes, akkor kiegyensúlyozott területi fejlödés jön-e létre, azaz csökkennek a területi különbségek? A fenti kérdések a mai napig heves vitákat váltanak ki a témával foglalkozó kutatók körében.

A közgazdaságtudományban két sarkos álláspont különíthető el aszerint, hogy a piaci automatizmusok szerepét hogyan ítélik meg. Az egyik álláspontra jellemző a komparativ elönyök érvényesülésének elfogadása, miszerint bizonyos feltételek fennállása esetén a piaci folyamatok automatikusan mérséklik a jövedelemeloszlások térbeli különbségeit, amennyiben a nemzetek (és régiók) közötti munkamegosztás a relatív költségelönyök szerint alakul (Krugman 1994; KrugmanObstfeld 2003). ,A komparativ elönyök törvénye szerint egy országnak azon árucikkek termelésére kell szakosodnia, amelyeket relative alacsonyabb költségen tud elóállítani, s azokat az árukat kell importálnia, amelyeket viszonylag magas költséggel termel." (Samuelson-Nordhaus 2000, 721) Tehát a nemzetközi gazdaságba mindenki be tud kapcsolódni, ha komparatív elönyei alapján szakosodik, azaz mindegyik ország és régió egyidejüleg fejlödhet. Ebben az esetben nincs értelme versenyről beszélni, mert lényegében mindenki győztes (Krugman 1994). 
A másik sarkos álláspont szerint a piaci automatizmusoktól nem várható a területi különbségek mérséklődése, ezért a kevésbé fejlett országokban, térségekben közösségi beavatkozásokra van szükség. Ezen irányzatcsaládon belül napjainkban a kompetitív elönyök elmélete került elótérbe, amely már nevében is deklarálja a területi versenyt. Ezen irányzat felfogása szerint a területi versenyben lehetnek győztesek és vesztesek, ezért mindegyik régiónak saját feltételeihez igazodó stratégiát kell kidolgoznia, hogy esélye legyen a sikerre. Magyarázatként gyakran felmerül, hogy a komparatív elönyök tana nem képes olyan tényezőket figyelembe venni, amelyek a globalizáció természetes velejárói, mint pl. a méretgazdaságosság szerepének felértékelődése, a vállalati hálózatok és stratégiai szövetségek megerősödése, a termelési tényezők országok közötti áramlása, a technológia-váltás, technológiatranszfer egyre növekvő jelentösége stb. (Lengyel-Rechnitzer 2004). Az EU regionális politikája is alapvetően a kompetitív irányzat szemléletét képviseli, hiszen a kevésbé fejlett régiók felzárkózásához támogatást nyújt, elöírva a partnerségen alapuló programozást, amely lényegében egy régió versenystratégiájának kidolgozását jelenti.

A két felfogás megjelenik a regionális tudományban, és jelentős erőfeszítések történtek a két álláspont viszonyának tisztázására is. Camagni (2002) szerint az árucserét, a kereskedelmet mozgató előnyöket élesen el kell különíteni egymástól két területi szinten: az egyik a nemzetgazdasági és metropolitan (világvárosi) régiók, a másik a többi régió és lokális területi egységek szintje. A nemzetgazdaságok (és metropolitan régiók) esetén értelmezhetö a komparatív előnyök fogalma, mert „nagy kritikus tömegúek”, felvevőképességük a gazdasági ágazatok többségének piaci igényeivel megegyezik. Viszont a kisebb városokkal bíró régiók és a lokális térségek a javak és a termelési tényezök országon belüli mozgása révén az abszolút előnyök (másképpen kompetitív elönyök) által generált interregionális kereskedelemben vesznek részt. Mindez azt jelenti, hogy nincs olyan hatékony piaci automatizmus, amelyik minden egyes területi egységnek hasonló szerepet biztosit a nemzetközi munkamegosztásban (Camagni 2002). Tehát szubnacionális régiókat tekintve a metropolitan régióknál komparatív, míg a többi területi egységnél inkább kompetitív elönyök szerint szerveződik a gazdaság.

Budd és Hirmis (2004) az elöbbi felosztásból kiindulva a komparatív és kompetitív előnyök eltérỏ térbeli érvényesülését az agglomerációs elönyökre $e^{l}$ vezeti vissza. A regionális versenyképesség kapacitás (RCC, Regional Competitiveness Capacity) modellje az X-hatékonyság ${ }^{2}$ elméletét használja, mint fogalmi alapot a kompetitív elönyök és a komparatív előnyök, illetve a hozzájuk tartozó szintek integrálására (1. ábra). A modell logikája értelmében a komparatív elönyök alapvetỏen nemzetgazdasági szinten jelentkeznek, míg a kompetitív előnyök vállalati szinten. A szubnacionális régiók esetében mindkét előny megfigyelhető, de eltérő erősséggel. $\mathrm{Az}$ urbanizációs ${ }^{3}$ előnyöket élvező, nagyvárossal bíró ('igy a 'metropolitan') régióknál inkább a komparatív, míg a kisebb városokkal rendelkező régióknál a lokalizációs ${ }^{4}$ elönyökre épülő kompetitív szemlélet áll közelebb a valóságos folyamatokhoz. 
Fenyővári Zsolt - Lukovics Miklós :

A regionális versenyképesség és a területi különbségek kölcsönhatásai.

Tér és Társadalom 22. évf. 2008/2. 1-20. p.

\section{1. ÁBRA}

Az RCC-modell logikai összefüggései

(Logical Relationships of RCC-model)

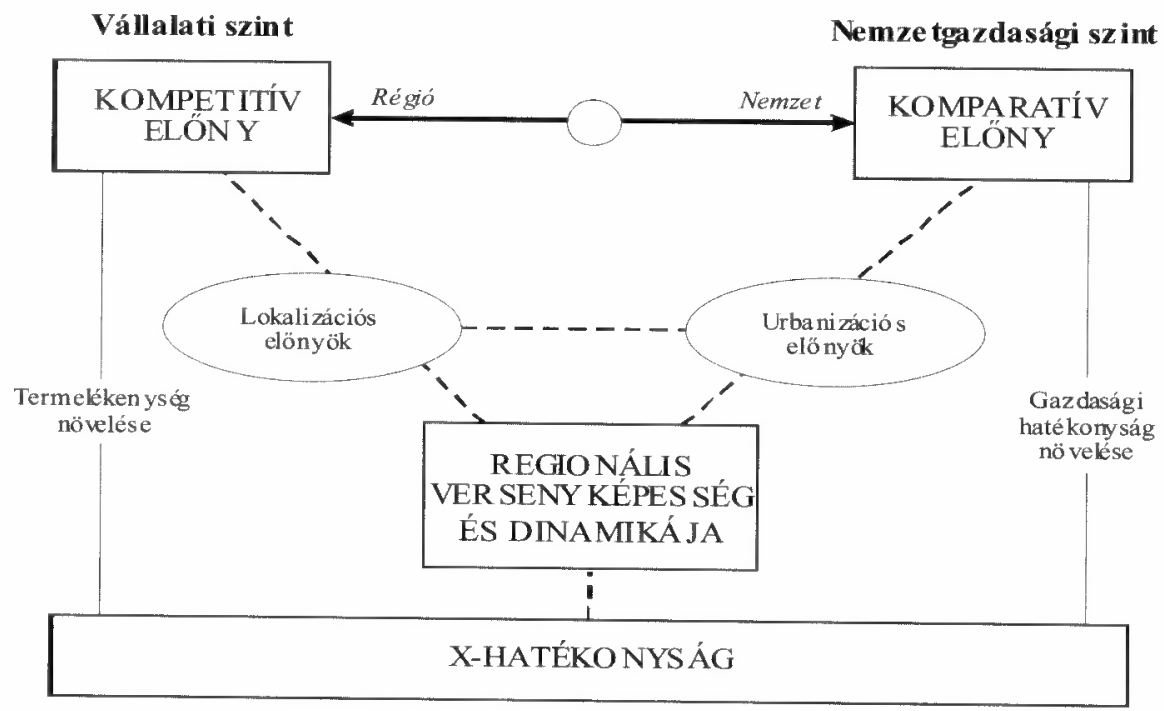

Forrás: Budd-Hirmis $(2004,1020)$ alapján saját szerkesztés.

Az RCC-modell is sugallja, hogy a régiók „gazdasági tömegüktöl”, felvevőpiacuktól, a munkaerỏtömeg nagyságától stb. függően eltérő módon vesznek részt a nemzetközi munkamegosztásban. Ezen gondolat mögött föleg a globális versenyben a közszolgáltatások méretgazdaságosságának felértékelödése áll. A kompetitiv elönyökből viszont következik, hogy a régiók versenyeznek egymással, de ez a területi verseny ${ }^{5}$ más módon múködik, mint a vállalati verseny (Lengyel 2003). Kérdés, hogy a régiók hasonló stratégiák kidolgozásával és végrehajtásával versenyeznek-e, vagy bizonyos régiótípusoktól függően más-más módon?

A területi versennyel és versenyképességgel, az egyes régiótípusoknak, illetve várostípusoknak a területi versenyben betöltött szerepével több empirikus vizsgálat foglalkozott. Az Európai Unió megbízásából a 2007-2013 közötti regionális politika megalapozására szolgáló egyik nagy volumenủ kutatás során a regionális versenyképességre ható tényezóket mérték fel (Martin et al 2003). Vizsgálatukban a regionális versenyképesség fogalmi megközelitését, a különféle elméleti közgazdasági irányzatok versenyképességgel kapcsolatos felfogását is áttekintették.

A régiókat két dimenzió, a népsürüség és a GDP növekedési üteme mentén sorolták alaptípusokba (Martin et al 2003): kozmopolita régiók, speciális városrégiók, dinamikus régiók, kiegyensúlyozott régiók, pihenő régiók, rurális régiók. A NUTS2 szintủ EU-s régiókat a nagy adatbázist alkalmazó empirikus kutatás végeredményeként ökonometriai módszereket alkalmazva három elméleti régiótípusba sorolták, amelyek más-más előnyökre alapozva vesznek részt a nemzetközi versenyben (2. ábra). 
Tér és Társadalom 22. évf. 2008/2. 1-20. p.

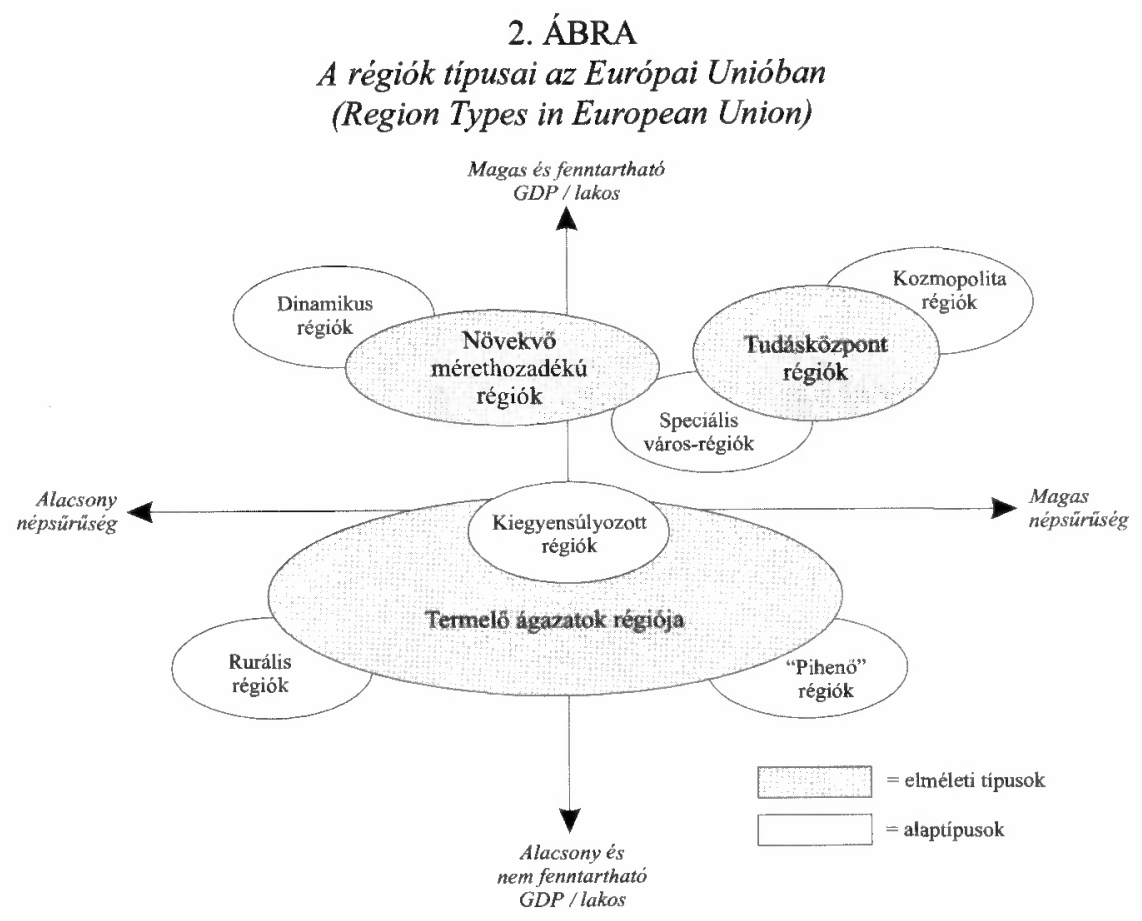

Forrás: Martin et al (2003, 6-23) alapján saját szerkesztés.

1) Termelö ágazatok régiója (regions as production sites): közepes jövedelmi szinttel leírható régiók. Ezen térségek vállalatai jellemzỏen az olcsó inputot hasznosítják, mint fơ versenyelőnyüket. Versenyképességüket leginkább a kiépült alapinfrastruktúra és olcsó telkek, valamint a relatíve olcsón elérhetó humán erőforrás határozza meg, amelyekre gyártó, összeszerelő telephelyek települnek. Mindezen jellemzók optimálisak a multinacionális vállalatok összeszerelő tevékenységei számára. Ezen térségekben közepes népsürüség, valamint átlagos GDP-növekedési ütem jellemző.

2) Növekvö mérethozadékú régiók (regions as sources of increasing returns): azon térségek tartoznak ide, amelyek gazdasági növekedése magas, míg népsürúségük közepes. Versenyképességüket leginkább a munkaerỏ képzettsége, a beszállítók elérhetősége, a piacméret határozza meg. Általában néhány húzóágazat biztosítja a térség jólétét.

3) Régió, mint tudásközpont (regions as hubs of knowledge): magas és fenntartható GDP-növekedés, valamint relatíve magas népsürüség jellemzi ezen térségeket. Nyitottak a nemzetközi kapcsolatokra, igen jó karrierlehetőségeket kínálnak, ami vonzza a tehetséges munkaeröt. Ezen térségtípusra a $\mathrm{K}+\mathrm{F}$ és az innováció magas szintje jellemző. Versenyelőnyük leginkább a humán erőforrás kimagasló minőségéből, a nemzetközi piacok egyszerü elérhetóségéből, valamint az üzleti szolgáltatások helybeli igénybevételének lehetôségeiböl származik. 
Fenyővári Zsolt - Lukovics Miklós :

A regionális versenyképesség és a területi különbségek kölcsönhatásai.

Tér és Társadalom 22. évf. 2008/2. 1-20. p.

$6 \quad$ Fenyövári Zsolt-Lukovics Miklós

TÉT XXII. évf. 2008

2

A régiók fenti három típusa hasonlatos Porter országokra adott felosztásához: tényezö-vezérelt, beruházás (hatékonyság)-vezérelt és innováció-vezérelt (Porter 2006). Szintén ezen három típus logikájához illeszkedik Lengyel (2003) tipizálása a tudásalapú posztfordista gazdaság régióira: neofordista, tudásalkalmazó és tudásteremtő régiók. Tötdling és Trippl (2005) a regionális innovációs lehetőségeket tekintve szintén három típust emelt ki: periférikus, ipari szerkezetváltási és nagyvárosi régió. Ezen csoportosítások egyértelmüen abból indulnak ki, hogy a globális munkamegosztásban a régiók mindegyik típusának eltérőek a lehetőségeik, másmás versenyelőnyökkel bírnak, azaz globális iparágaik eltérő stratégiákat képesek csak alkalmazni a nemzetközi versenyben.

\section{3. ÁBRA}

Az eltérö típusú régiók versenyképességét magyarázó közgazdasági irányzatok (The Economic Tendencies Explaining the Competitiveness of the Different Types of Regions)

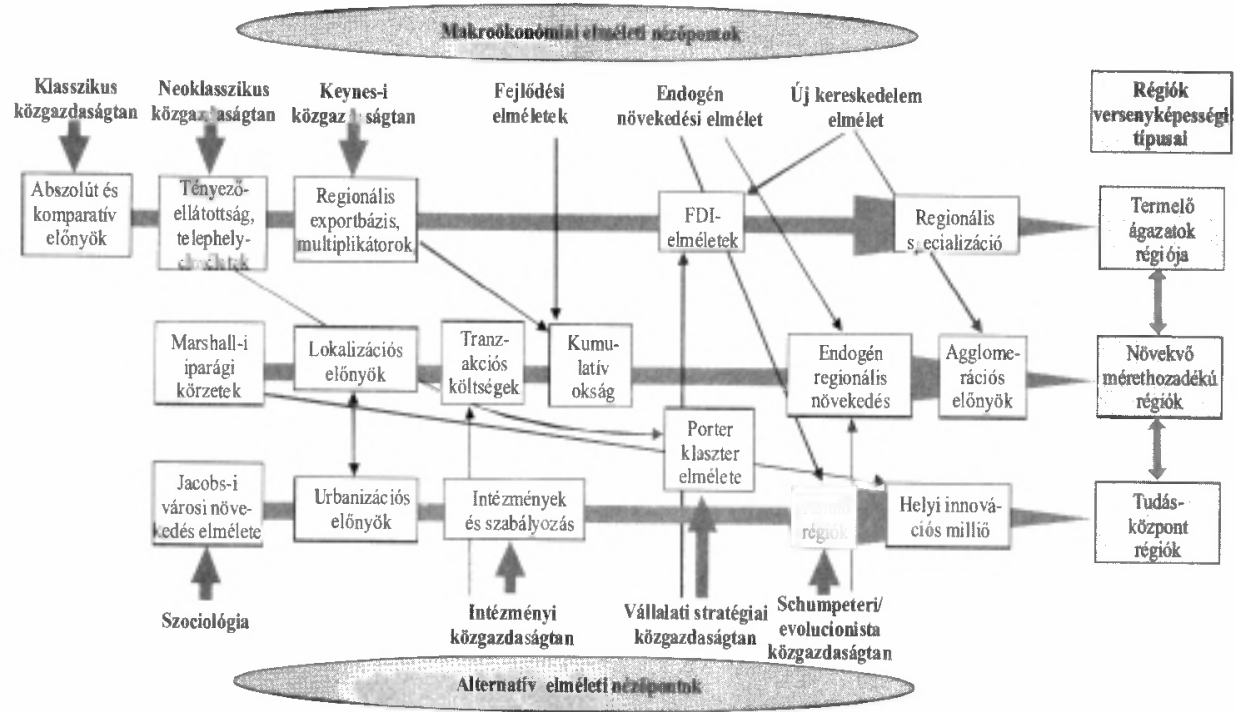

Forrás: Martin et al (2003, 2-14).

Az EU-s vizsgálat során a versenyképességgel foglalkozó közgazdaságtani irányzatokat áttekintve megállapították, hogy az eltérỏ régiótípusok fenntartható gazdasági növekedését más-más elméleti közgazdaságtani irányzatok fogalomrendszerében lehet megfelelöen leírni (Martin et al 2003). Az általuk vizsgált elméleti közgazdaságtani irányzatokat két nagy csoportra bontották, elkülönítették a makroökonómiai irányzatokat az alternatív irányzatoktól, melyek eltérő módon itélik meg a regionális versenyképességet, illetve speciális típusú régiók versenyképességének magyarázatára alkalmazhatók (3. ábra). Lényegében arról van szó, hogy a régiók fenntartható gazdasági növekedésének eltérőek az alaptényezői fejlettségüktől és gazdaságfejlesztési lehetőségeiktöl függỏen, miközben a többi, eltérö típusú régióval is versengenek. 
A közgazdaságtani elméletek két csoportja jelzi azt is, hogy a makroökonómiai irányzatok többsége az országok komparatív elönyeit tartja fontosnak, míg az alternatív irányzatok inkább a szubnacionális régiók kompetitív elönyeit.

A fenti speciális régiótípusok eltérö módon vesznek részt a területi versenyben, más tényezökböl erednek versenyelönyeik (Martin et al 2003):

- A termelö ágazatok régiója versenyelönyeit a költségelönyökre alapozott nemzetközi munkamegosztás eröteljesen befolyásolja. Ebben az esetben a gazdasági tevékenységeket a hagyományos telepítési tényezők (természeti kincsek elérhetősége, nagy tömegben rendelkezésre álló munkaerö, piacok elérhetősége stb.) térbeli elhelyezkedése határozza meg. Ennek következtében komparativ elönyökön alapuló nemzetközi munkamegosztás jön létre, melyben a gazdasági teljesítményt alapvetően befolyásolja az exportra termelő iparágak relatív nagysága és sikeressége. Ezen régiótípusok versenyképességét meghatározó tényezök tárgyalására elsősorban a makroökonómiai irányzatok, azon belül is a klasszikus, a neoklasszikus, valamint a Keynes-i közgazdaságtan alkalmasak.

- A növekvö mérethozadékú régiók versenyképességét befolyásoló tényezök tárgyalására egyaránt fel lehet használni a makroökonómiai és az alternatív irányzatokat. A növekvő mérethozadék első számú forrása egy kumulatív folyamat, melynek keretén belül a régióban termelt outputok iránti régión kívüli élénk kereslet a nagyobb regionális kibocsátáson és a termelékenység növekedésén keresztül visszahat a régióban termelt outputok keresletére. Ebben a folyamatban kiemelt szerepet kapnak a régió endogén forrásai, a specializáción alapuló vállalati együttmúködés, valamint a térbeli koncentráció, melyek a tranzakciós költségek jelentös csökkentéséhez, valamint a lokalizációs elönyök érvényesüléséhez vezethetnek. Ezen régió-típus versenyképessége az endogén növekedési elmélettel, a fejlődési elméletekkel, az új kereskedelem elmélettel és az evolucionista közgazdaságtannal, közvetve pedig a Keynes-i közgazdaságtannal hozható kapcsolatba.

- A tudásközpont régiók versenyképességében a tudás szerepe domináns, ahol a tapasztalatcserében (interaktív tanulásban) kiemelt szerepet kap a párbeszéd, a közös tanulás és a helyi innovációs miliő is. Az innovációs miliő lényegét a térbeli koncentráció adja, mely lehetővé teszi, hogy közös értékrend, értelmezési mód, kódok, a valahova tartozás érzése, közös szakmai háttér alakuljon ki. A tudásközpont régiók versenyelőnyeit meghatározó tényezök tárgyalására jellemzöen az alternativ közgazdasági irányzatok fogalmai tünnek alkalmasnak: az innováció kiemelt szerepét valló evolucionista közgazdaságtan, az új intézményi közgazdaságtan, valamint az urbanizációs elönyöket hangsúlyozó Jacobs-féle városi növekedéselmélet.

A szakirodalom rövid áttekintése után egyértelmüen kijelenthetö, hogy a szubnacionális régiók fejlődésének tényezőit, mozgatórugóit tekintve a regionális tudományban a korábbi egyoldalú állásfoglalások helyett árnyaltabb megközelítések nyertek teret. Széles körben egyre elfogadottabb álláspontnak tünik, hogy míg a nem- 
zetközi munkamegosztást országok és metropoliszok esetében a komparatív előnyök spontán módon befolyásolják, addig a szubnacionális területi egységek többségénél a fejlődést a kompetitív előnyök kihasználása határozza meg. A régiók típusától nagyban függnek az ott megjelenö kompetitiv elönyök, amelyeket a különböző elméleti irányzatok más-más fogalomrendszerrel próbálnak leírni. A tanulmány további részében néhány kiemelt elméleti közgazdaságtani irányzat területi versennyel és versenyképességgel kapcsolatos legfontosabb szempontjait tekintjük át; az irányzatok alapgondolatai hogyan hozhatók kapcsolatba a területi különbségek értelmezésével.

\section{A regionális versenyképesség értelmezése az elméleti közgazdasági irányzatoknál}

Tanulmányunkban a versenyképesség többféle elfogadott definíciója közül az egységes versenyképesség fogalmát használjuk (EC 1999; Lengyel 2003, 278); „, a vállalatok, iparágak, régiók, nemzetek és nemzetek feletti régiók képessége relative magas jövedelem és relative magas foglalkoztatottsági szint tartós létrehozására, miközben a külgazdasági (globális) versenynek ki vannak téve". Ezt a legáltalánosabb fogalmat választottuk annak érdekében, hogy az egyes elméleti közgazdaságtani irányzatok mondanivalóját ne szükítsük le a konkrétabb definíciók által meghatározott értelmezési tartományba. Emiatt lényegében a területi versenyben való sikeres helytállás, a tartós gazdasági fejlödés képességét értjük a továbbiakban versenyképesség alatt, ami a GDP növekedésében és ezen keresztül a jólét emelkedésében jelenik meg. A közgazdaságtani irányzatok nyilvánvalóan tárgyalják a gazdasági növekedést és tényezöit, a versenyképesség fenti fogalma pedig a magas foglalkoztatottsági szint melletti gazdasági növekedést emeli ki. Mivel a területi különbségeket is a GDP-ben mért gazdasági növekedés, vagy a gazdasági fejlettség/fejlődés egyéb mérőszámaival szokás mérni, emiatt a versenyképesség és területi különbségek kapcsolatát is általánosan vizsgálni tudjuk.

Az elöző fejezetben említett makroökonómiai és alternatív irányzatok közül (lásd 3. ábra) a továbbiakban az általunk fontosnak tartott nyolc elméleti közgazdaságtani irányzat mondanivalóját és fogalomkészletét tekintetjük át. Megjegyezzük, hogy a makroökonómiai irányzatok közül a fejlődési elméletekkel, valamint az alternatív irányzatok közé sorolt szociológiával jelen tanulmányunk nem foglalkozik. A vizsgálatba bevont kiemelt elméleti közgazdasági irányzatok a következők:

1) klasszikus közgazdaságtan,

2) neoklasszikus közgazdaságtan,

3) Keynes-i közgazdaságtan,

4) endogén növekedési elmélet,

5) új kereskedelem elmélet,

6) intézményi közgazdaságtan,

7) vállalati stratégiai közgazdaságtan,

8) evolucionista közgazdaságtan. 
A nyolc kiemelt elméleti közgazdaságtani irányzat áttekintésekor arra törekszünk, hogy szintetizáljuk az egyes irányzatok lényegét, megvizsgálva azt, hogy fogalomrendszerükben a területi verseny egyáltalán értelmezhetö-e, és a területi különbségek mérséklödése a piaci automatizmusok hatására végbe mehet-e. Áttekintjük, hogy melyek az adott irányzat regionális versenyképességgel kapcsolatba hozható kulcsfogalmai és alapgondolatai (1. táblázat). Mivel önmagukban koherens irányzatokról van szó, ezért több esetben az alkalmazott fogalmak az irányzatok „nyelvétöl" függöen másképp értelmezhetök.

A klasszikus közgazdasági elmélet Smith munkásságából kiindulva a gazdasági növekedés hordozójaként $a$ munkamegosztást - illetve annak szükségszerü következményét, a cserét - és a tökefelhalmozást nevezi meg (Mátyás 2002). Ebben a megközelítésben a tókébe és a kereskedelembe történő beruházás előmozdítja a specializációt, növeli a termelékenységet és az output növekedési ütemét. Az országok közötti kereskedelem a termelékenységben fennálló abszolút különbségeknek, azaz abszolút elönyöknek tulajdonítható (Martin et al 2003).

Ricardo azt is be tudta bizonyítani, hogy a nemzetközi munkamegosztás és a kereskedelem még a relativ (komparativ) költségelönyök mellett is jövedelmezö (Samuelson-Nordhaus 2000; Krugman-Obstfeld 2003). A javak piaci ára szükségképpen igazodik az előállitásukkal kapcsolatos élőmunka- és tőkeráfordások relatív nagyságához. Ez az alkalmazkodás a versenypiacon megy végbe. Mindez a szuverén gazdasági szereplök racionális döntéseinek köszönhető, akik a rendelkezésükre álló erőforrások hatékony hasznosítására törekszenek. A termelők által így elérhető „rendes profit” (mai szóhasználattal élve: normál profit) biztosítja a jólét maximumát. ,... ez állja útját annak, hogy a javak piaci ára hosszabb idỏn át jelentékenyen a természetes ár felett vagy alatt maradjon. És ez a verseny alakítja ki a javak változó értékét olyan módon, hogy [...] a megmaradó érték, vagyis felesleg minden termelési ágban a befektetett töke értékével lesz arányos" (Ricardo 1940, 60). A klasszikus közgazdaságtanban tehát a verseny a gondolkodás középpontjában áll, mindez azonban az egyéni aktorok cselekvéseit mozgatja, a területi verseny, mint kérdésfeltevés az ipari forradalom korában nem értelmezhetö.

Annak ellenére, hogy az adott történelmi és gazdasági körülmények között a területi verseny nem volt aktuális probléma, a klasszikusok versenyabszolutizáló elképzelése adaptálható napjaink országok és régiók közötti versenyére is. A klasszikusok munkásságának legfontosabb üzenete a versenyképesség szempontjából az, hogy minden országnak az abszolút és a relatív előnyére egyaránt támaszkodó szerepe van a munkamegosztásban. Azonban, ha a technológia és ennél fogva a termelékenység ugyanaz az országok vagy régiók között, akkor a kereskedelemnek nincs alapja. Lényeges ugyanakkor, hogy a munkamegosztás természetesen a társadalmi szintü kibocsátás (jólét) növekedését is eredményezi. A szakosodással esetenként együtt járó jelenségek (növekvő skálahozadék, koncentrált iparági tudás) a versenyképesség növekedésének további forrásait jelenthetik. Témánk szempontjából a fentiek persze úgy is értelmezhetők, hogy a komparatív elönyök révén kialakuló szakosodás következtében elmélyülö (az egyes régiókra jellemzö) hatékonyságelőnyök végső soron úgy járulhatnak hozzá a területi különbségek mérséklődéséhez, hogy ez valamennyi érintett régió javára válik. 


\begin{tabular}{|c|c|c|c|}
\hline \multicolumn{4}{|c|}{$\begin{array}{c}\text { 1. TÁBLÁZAT } \\
\text { Az elméleti közgazdaságtani irányzatok területi versennyel és versenyképességgel, } \\
\text { valamint a területi különbségekkel kapcsolatos kiemelt szempontjai } \\
\text { (The Emphasized Aspects of Theoretical Economic Tendencies Related to Regional } \\
\text { Competition, Competitiveness and Regional Differences) }\end{array}$} \\
\hline $\begin{array}{l}\text { Irányzatok } \\
\text { megnevezése }\end{array}$ & $\begin{array}{c}\text { Területi } \\
\text { versenyról } \\
\text { alkotott nézet }\end{array}$ & $\begin{array}{l}\text { Terïleti } \\
\text { különbségek a } \\
\text { piaci automa- } \\
\text { tizmusok hatá- } \\
\text { sára mérsék- } \\
\text { lödhetnek-e }\end{array}$ & $\begin{array}{c}\text { Az irányzat regionális verseny- } \\
\text { képességgel kapcsolatba hozható } \\
\text { kulcsfogalmai, } \\
\text { illetve alapgondolatai }\end{array}$ \\
\hline $\begin{array}{l}\text { Klasszikus } \\
\text { közgazdasági elmélet }\end{array}$ & $\begin{array}{l}\text { Eredeti } \\
\text { modellben nem } \\
\text { értelmezett }\end{array}$ & Igen & $\begin{array}{l}\text { Specializáció, munkamegosztásra épülö } \\
\text { kereskedelem, termelékenységkülönb- } \\
\text { ségek. }\end{array}$ \\
\hline $\begin{array}{l}\text { Neoklasszikus } \\
\text { közgazdasági elmélet }\end{array}$ & Elveti & Nem & $\begin{array}{l}\text { A neoklasszikus növekedési modellek } \\
\text { alapfeltevései lehetetlenné teszik azt, } \\
\text { hogy a regionális versenyképesség } \\
\text { fogalmát a neoklasszikus elméleti hát- } \\
\text { tér adta korlátok között tárgyaljuk. } \\
\text { Területi folyamatokkal kapcsolatos } \\
\text { legfontosabb elméleti kategóriája az } \\
\text { externáliák fogalomköre. }\end{array}$ \\
\hline Keynes-i elmélet & $\begin{array}{l}\text { Tudomásul } \\
\text { veszi }\end{array}$ & Nem & $\begin{array}{l}\text { Gazdaságpolitika, állami beavatkozá- } \\
\text { sok, költségvetési kiadások, intézmé- } \\
\text { nyek. }\end{array}$ \\
\hline $\begin{array}{l}\text { Endogén növekedési } \\
\text { elmélet }\end{array}$ & $\begin{array}{l}\text { Tudomásul } \\
\text { veszi }\end{array}$ & Igen & $\begin{array}{l}\text { Tudás, technológia, mint a térség belsỏ } \\
\text { eróforrásai endogének. }\end{array}$ \\
\hline Ủj kereskedelemelmélet & Elveti & Nem & $\begin{array}{l}\text { A teljes térgazdaságtani építmény nem } \\
\text { alkalmas a versenyképesség fogalmá- } \\
\text { nak tárgyalására, hiszen felfogása sze- } \\
\text { rint a spontán piaci folyamatok alakít- } \\
\text { ják a régiók közötti termelékenységi } \\
\text { különbségeket. A területi folyamatok- } \\
\text { kal kapcsolatos kiemelt kategóriái: } \\
\text { térbeli specializáció, agglomerálódás, } \\
\text { klaszteresedés. }\end{array}$ \\
\hline $\begin{array}{l}\text { Intézményi } \\
\text { közgazdaságtan }\end{array}$ & $\begin{array}{l}\text { Tudomásul } \\
\text { veszi }\end{array}$ & Igen & $\begin{array}{l}\text { Az intézmények kiemelt szerepe, } \\
\text { tranzakciók, tranzakciós költségek } \\
\text { térbelisége, a tulajdonjogok érvényesù- } \\
\text { lésének kitüntetett jelentôsége. }\end{array}$ \\
\hline $\begin{array}{l}\text { Vállalati stratégiai köz- } \\
\text { gazdaságtan }\end{array}$ & Abszolutizálja & Nem & $\begin{array}{l}\text { Kompetitiv elönyök előtérbe kerülése, } \\
\text { méretgazdaságosság, növekvő skála- } \\
\text { hozadék, a vállalati hálózatok és straté- } \\
\text { giai szövetségek megerösödése, } \\
\text { klaszterek, a termelési tényezök orszá- } \\
\text { gok közötti áramlása, a technológia, } \\
\text { technológiatranszfer. }\end{array}$ \\
\hline $\begin{array}{l}\text { Evolucionista } \\
\text { közgazdaságtan }\end{array}$ & Abszolutizálja & Igen & $\begin{array}{l}\text { A regionális versenyképesség a térség } \\
\text { történelmi múltjában gyökerezik, } \\
\text { azonban az új technológiák és új in- } \\
\text { tézmények a gazdasági növekedés új } \\
\text { ösvényét jelölhetik ki. }\end{array}$ \\
\hline
\end{tabular}


A neoklasszikus közgazdasági elmélet megkérdőjelezhetetlenül versenycentrikus modell (Mátyás 1993). Elsősorban mikroökonómiai alapokon építkezve továbbfejleszti a klasszikusok gondolatait. Témánk szempontjából két vonulat tủnik relevánsnak: a marginalista szemléletmód eluralkodása és az önszabályozó piaci mechanizmusok hegemóniája. Mindkettó ugyanabba az irányba mutat, a piaci versenynek nincs alternatívája. A kompetitív mechanizmusok révén kialakuló Pareto-hatékony erőforrás-allokációnak köszönhetóen jóléti veszteség - általában - nem keletkezik. A neoklasszikus iskola által szintén preferált - komparativ elönyök és hátrányok a modell feltételeiből fakadóan hosszú távon szükségszerúen eltünnek (Krugman-Obstfeld 2003). Másrészröl a piactisztító árak mikro- és makroszintü dominanciája arra enged következtetni, hogy a versenyidegen jelenségek (legyen az állami beavatkozás vagy bármely versenykorlátozó megnyilvánulás) hatékonyság-veszteséggel jámak.

A fentiek ellenére a neoklasszikus modell alapfeltevései - tökéletes informáltság, állandó skálahozadék, a hosszú távon érvényesülő egyensúlyi helyzet, és föként a teljes tényezőmobilitás és tökéletes verseny - és eszközrendszere azonban a regionális versenyképesség fogalmának értelmezését lehetetlenné teszik. ${ }^{6}$ Török Ádám (1999) szintén arra az álláspontra helyezkedett, hogy a neoklasszikus közgazdaságtan fogalomrendszere alapján nem értelmezhetö az országok, így a területi egységek közötti verseny. A Solow-féle neoklasszikus növekedési modell - a tanulmány témája szempontjából - legfontosabb erőssége az, hogy azonosítja a technikát, mint a növekedés hordozóját, ami a közismert versenyképességi felfogásokkal is összhangban áll. A neoklasszikus növekedési modellben a technikai fejlödés exogén változó, ami esetünkben annyit tesz, hogy az minden régiót egyformán érint. A tényezök - így a technológia - régiók közötti abszolút mobilitásának feltételezése miatt a modellben hosszú távon minden különbség - így a régiók között fennálló bármilyen fejlettségi különbség is - eltünik. Ha pedig a regionális különbségek kialakulásának és tartós fennmaradásának a neoklasszikus iskola nem enged teret, értelemszerúen azok mérsékl(őd)ése sem értelmezhető. Annak ellenére, hogy a neoklasszikus irányzatban nem értelmezhetỏ a regionális versenyképesség, az eltérỏ régió-típusok gazdasági jellemzőinek leírására részletes eredmények születtek: a telephelyelméletek, az iparági körzetek (lokális pozitív extern hatások) és a nagyvárosi növekedés elmélete (lásd 3. ábra).

A Keynes-i elmélet azzal, hogy kimondta, a piacok nincsenek szükségszerüen egyensúlyban, hallgatólagosan elfogadja a regionális egyenlőtlenségeket (Mátyás 1993). A Keynes-i teória szerint a verseny a modern piacgazdaság alapintézménye, ám önmagában nem képes biztosítani a társadalmi jólét maximumát, így a versenyt, mint alapintézményt ki kell egészíteni az aktív kormányzati beavatkozással. A kihasználatlan kapacitások (közöttük kitüntetetten az alacsony foglalkoztatási szint) ugyanis jóléti veszteséggel járnak, az aktív regionális kormányzati szerepvállalás tehát nem nélkülözhetö. Ugyanez érvényes a régiók szintjén is, hosszabb távon nagyobb a közösségi beavatkozás haszna, mint az elmaradt beavatkozás miatti veszteség.

A modell nemzetgazdasági szinten tudatosan változtatható jövedelemmel számol, ennek egy lehetséges olvasata, hogy a bővülő kormányzati kiadások kapcsán tapasz- 
talható - és a neoklasszikusok által sokat emlegetett - kiszorítási hatás nem, vagy kevésbé érvényesül. Emiatt a Pareto-i értelemben vett hatékonyság-követelmény nem sérül, miközben a differenciált költségvetési beavatkozások, illetve azok multiplikatív hatása révén a nem kívánt regionális termelékenységi (versenyképességbeli) különbségek mérséklődnek, vagy az éppenséggel kívánatos versenyelönyök megerősödnek. A folyamat jótékony kísérőjelensége a növekvő foglalkoztatottsággal együtt járó keresletnövekedés, amely közismerten a Keynes-i gazdaság motorja.

A Keynes-i elméletnek fontos álláspontja a területi különbségek elfogadása, a kormányzati intervenciók gazdasági ciklusokra gyakorolt hatásának felismerése, a régiók felzárkózásában a gazdaságpolitika szerepének hangsúlyozása, valamint a tökeintenzitásnak a termelékenységre és a gazdasági növekedésre gyakorolt hatása (Martin et al 2003). A Keynes-i teória az eddig tárgyalt irányzatok közül tehát elöször ismeri fel az intézmények, központi és helyi kormányzatok gazdasági növekedésre és fejlödésre gyakorolt hatását, ami a regionális versenyképességet meghatározó faktorok közül az empirikus elemzések tanúsága szerint az egyik legfontosabb. A fentiek értelmében a Keynes-i teória fogalomrendszere egyértelmüen alkalmas mind a regionális versenyképesség, mind a terület- és gazdaságfejlesztés elméleti megalapozására, hasonlóképpen bőséges fogalom- és eszköztárat kínál a területi különbségek tudatos mérséklésének lehetőségeire is. Másképpen fogalmazva: a területi különbségek mérséklődése spontán piaci folyamatként nehezen értelmezhető, a kívánatos folyamatok sokkal inkább tulajdoníthatók egy tudatos intézményi beavatkozás következményeinek. A regionális gazdaságfejlesztésben széles körben alkalmazott gazdasági báziselmélet lényegében a Keynes-i gondolatok aktualizálását jelenti, amikor a regionális multiplikátor-hatásoktól várja a területi különbségek mérséklődését (Lengyel-Rechnitzer 2004). A Keynes-i elmélet részeként mindegyik régiótípus versenyképességének javítására megjelentek a speciális gondolatok: exportbázis elmélet, lokalizációs és urbanizációs elönyök elmélete (lásd 3. ábra).

Az endogén növekedési elmélet a technikai fejlődés, a humántöke-felhalmozás explicit modellezésével elemzi a gazdasági növekedést (Lucas 1988; Romer 1990; Szentes 2005). A neoklasszikus növekedési modellben említett exogén technikai fejlődés feltételezésével ellentétben az endogén növekedési elmélet szerint a technikai haladás többé nem exogén változó, hanem racionális gazdasági döntéshozói tevékenység eredménye. A humán tőke-felhalmozáshoz az emberek közötti kapcsolattartásra, a már megszerzett tudás átadására van szükség, vagyis a humán tóke bővülése annak múltban elért szintjétől függ. Továbbá a humán tőkének el kell érnie egy kritikus szintet ahhoz, hogy növekedés forrása lehessen, ez alatt növekedést érdemben nem tud generálni. A humán tőke és a technológia régiónként eltérő (endogén) fejlödésének következtében kialakuló termelékenységbeli területi különbségek tartósan fennállnak. A tökéletes informáltságra, egyforma termelési (és költség-) függvényekre épitő kompetitív piaci modell a valóságban nem érvényesül, mivel a piacok tökéletlenek.

$\mathrm{Az}$ endogén növekedési modellek másik alapvető típusa az innovációt helyezi a vizsgálatok középpontjába (Valentinyi 1995). A találmányok jellege hasonlatos a közjavakéhoz. Egy találmányt egyszerre akár többen is használhatnak, másrészt a 
 \\ Fenyővári Zsolt - Lukovics Miklós :}

A regionális versenyképesség és a területi különbségek kölcsönhatásai.

Tér és Társadalom 22. évf. 2008/2. 1-20. p.

TÉT XXII. évf. 2008 - 2 A regionális versenyképesség és a ...

találmány tulajdonosa jogi eszközökkel sohasem zárhatja ki tökéletesen annak használatából azokat, akik ezért nem fizettek. A találmány sokrétủ hasznosítása révén folyamatos horizontális termékdifferenciálódás megy végbe, így végső soron a gazdaság hatékonysága nő. Az uralkodó piacforma pedig a monopolista verseny lesz, az esetenként eltérő hasznosítási módok versenyelönyök és -hátrányok kialakulásához vezetnek. $\mathrm{Az}$ egyes gazdasági rendszerekben nem feltétlenül a Shumpeter-i értelemben vett technológiaváltás a jellemzö, sok helyütt a régi és új technológia egymás mellett élése jelenik meg, amely újfent átrendezheti a „versenytérképet”.

Ki kell emelni, hogy az endogén növekedési elméletnek a fentiektól eltérő értelmezési lehetöségét is használjuk a regionális gazdaságtanban. Ugyanis nemcsak a technológiát tekintjük belsőnek, amikor endogén növekedési elméletröl beszélünk, hanem a térség saját belső erőforrásait is, amelyek a növekedés hordozóiként funkcionálnak.

$\mathrm{Az}$ endogén növekedési modellekben a területi verseny tehát értelmezhetö, de mindez tökéletlen verseny formájában valósul meg, ahol tartós versenyelőnyök keletkeznek. Tekintettel arra, hogy a modell többségében napjainkban érvényes alapfeltevésekböl indul ki, a tudásalapú gazdaság leírására is használható, emiatt az endogén növekedési elmélet fogalmai és eszközrendszere mindenképpen alkalmasak a regionális versenyképesség tárgyalására.

A technológia, a tudás, valamint a térség saját eröforrásainak endogén változóként való szerepeltetése az endogén növekedési elmélet legfontosabb, a versenyképesség fogalmát alapvetően meghatározó újdonsága. A modell értelmében a tudás felhalmozódása növekvő skálahozadékot eredményez, a termelékenység növekedése ennek értelmében a tudás és a technológia térbeli terjedésének következménye, ami nem hordoz semmiféle, a területi egyenlötlenségek csökkentésére irányuló automatizmust. Megjegyzendỏ azonban, hogy az említett endogén tényezők fejlődését célzó tudatos regionális (gazdaság)politika hatékony eszköze lehet a területi lemaradások mérséklésének, így dolgozatunk alapproblémája e gondolatrendszerbe beilleszthető. $\mathrm{Az}$ endogén növekedési elmélet mindegyik régiótípus versenyképességének leírására alkalmas, a termelő ágazatok régiója esetében a külföldi működő tőke bevonását, a másik két típusnál a klaszterek fejlesztését elỏtérbe állítva.

Az új kereskedelem elmélet alapköveként a Dixit és Stiglitz-féle monopolisztikus versenymodell tekinthető, melynek a térben való újrafogalmazása az új gazdasági földrajz keretében történt (Krugman-Obstfeld 2003, Varga 2003). Térbeli relevanciája miatt a továbbiakban az új gazdasági földrajz (NIG, new economic geography) alapgondolataira koncentrálunk (Krugman 2000). Az 1990-es évek elejétöl elötérbe kerülő elméleti közgazdaságtani irányzatok müvelöi szerint a globalizáció hatásainak következtében a közgazdaságtan korábbi fogalomtára és eszközei kevéssé alkalmasak napjaink gazdasági folyamatainak leírására, így pl. a verseny hagyományos értelmezésére. A térgazdaságtan, vagy új gazdasági földrajz az 1990-es évek elején bontakozott ki, mint a "tér újrafelfedezésének" egyik legfontosabb irányzata (Lengyel 2003; Varga 2003). Krugman a termelés térbeli elhelyezkedésének vizsgálatára helyezte kutatásának fókuszát, melynek keretén belül elsősorban a gazdasági tevékenységek térbeli struktúrájának kialakulását és változását modellezte, nagy hang- 
súlyt fektetve a térbeli koncentrációkra (Lengyel-Rechnitzer 2004). Kiinduló feltevései között kiemelten fontos szerepet kapnak a növekvő skálahozadék, a tökéletlen verseny, a fajlagos szállítási költségek csökkenése, a lokális extern hatások ( $\dot{A} c s-$ Varga 2000).

Krugman szerint a komparatív előnyök alapján specializálódó országok/régiók mindegyike nyertes lehet. A centripetális és a centrifugális erők révén a térbeli egyensúly Pareto-hatékony, így nincs értelme terïleti versenyröl, ezáltal versenyképességröl sem beszélni. A fentiek logikus következménye, hogy a termelékenység regionális eltérései elsősorban a térbeli specializáció, az agglomerálódás, valamint a klaszteresedés eltérő szintje következtében alakulnak ki. Bár az irányzat több gondolata összecseng a regionális versenyképesség logikájával ${ }^{7}$, a teljes térgazdaságtan építménye nem alkalmas a versenyképesség fogalmának tárgyalására, hiszen felfogása szerint a spontán piaci folyamatok alakítják a régiók közötti termelékenységi különbségeket (Lengyel 2003), ugyanakkor segítségével a területi különbségekre kielégítő magyarázat adható.

Az intézményi közgazdaságtan vizsgálódása föként a gazdasági, társadalmi és politikai intézmények magyarázatát foglalja magában (Mátyás 1996; Coase 2005). Kutatásának fókusza annak tanulmányozása, hogy miért és hogyan alakulnak ki a különbözö intézmények, melyek az emberi magatartásnak keretet szabnak, illetve adott interakciókat megszerveznek. Megjegyezzük, hogy intézmény alatt nem egy szervezetet, hanem a gazdaság müködésének alapvető jellemzőit értjük, pl. a magántulajdon, a piacok, a vállalaton belüli koordináció mikéntje. Az irányzat az intézményeket kiemelt fogalomként kezeli, akárcsak a tranzakciókat, valamint az egyes intézményekhez köthetö tranzakciós költségeket. A versenyt alapintézménynek tartja, ugyanis fogalomrendszerében a hagyományos marginalista megközelítés nem sérül, megjelennek azonban a termelési és költségfüggvények mellett a tranzakciós függvények (North 2005) és a tranzakciós költségek ${ }^{8}$ (Williamson 2005). $\mathrm{Az}$ intézményi közgazdaságtani irányzat másik sarokköve a tulajdonjogok elmélete. Képviselői szerint a kompetitív piaci mechanizmusok révén általában érvényesülő Pareto-hatékony allokáció (vagyis a társadalmi jólét) nélkülözhetetlen feltétele a tulajdonviszonyok egyértelmüsége és a tulajdonjogok maradéktalan érvényesíthetösége (Pejovich 1992). Így aztán jelentősen bővül a vizsgált változók köre, a régiók közötti termelékenységbeli különbségek az intézményi tényezők figyelembevételével újraértelmezett versenymodell keretei között érvényesülnek.

A regionális versenyképességet alapvetően meghatározza a vizsgált régió tágan értelmezett (makrogazdasági) intézményi környezete, továbbá az ezekkel kapcsolatba hozható tranzakciós költségek: keresési és információs, kommunikációs, koordinációs költségek, alku- és döntési költségek, ellenörzési és kikényszeritési költségek (Schumann 1998; Martin et al 2003). Ez a kibővített feltételrendszer napjaink gazdasági folyamatainak komplexitását megfelelö érzékenységgel kezeli. Ennek következtében az intézményi közgazdaságtan fogalomrendszere és eszköztára kiválóan alkalmas a területi verseny és a regionális folyamatok tárgyalására. Hasonlóképp, a szúkebben értelmezett gazdasági folyamatok és az intézményi feltételek 
dinamikus kölcsönhatásából fakadó állandó változás következtében a területi különbségek elmélyülése vagy mérséklődése a modell keretei között jỏl kezelhetők.

A vállalati stratégiai közgazdaságtan és a kompetitív elönyök elmélete nagymértékben összekapcsolható Michael Porter munkásságával (Porter 1998). Mint említettük, Porter szerint a globalizáció háttérfolyamatait a komparativ elönyök helyett a kompetitiv előnyök fogalomkörében lehet magyarázni, hiszen utóbbi olyan tényezöket is képes figyelembe venni, amelyeket elöbbi nem, és amelyek a globalizáció természetes velejárói, és a világgazdaságban megkérdőjelezhetetlenül jelen vannak. A versenyelönyök tehát a vállalati stratégiai közgazdaságtan alapfogalma, melyben belső tényező a méretgazdaságosság, a vállalati hálózatok és stratégiai szövetségek megerősödése, a termelési tényezök országok közötti áramlása, a technológia, technológia-transzfer egyre növekvő jelentősége stb. A hazai szakirodalom vállalati és iparági szinten a „versenyelőnyök”, míg a területi egységek esetében „kompetitív előnyök" kifejezést használja (Lengyel-Rechnitzer 2004).

Porter elfogadja a területi verseny létezését, amit a térségben mủködő húzóágazatokra, klaszterekre vezet vissza (Lengyel 2003). A területi versenyböl adódóan a regionális versenyképességet is értelmezi, elsősorban, mint a régióban elért termelékenység adott szintjét és növekedési ütemét. Felfogásában a regionális gazdaságfejlesztés célja a régióban élök jólétének növelése, eszköze a régió versenyképességének javítása, amit az alulról szerveződő (bottom-up) stratégiákkal lehet elérni. Porter „vállalati stratégia közgazdaságtanában" közismerten a mikroökonómiai alapokra koncentrál, ily módon a régió tényezőellátottsága is fontos szerepet kap, azonban elsősorban a domináns iparágak (klaszterek) szükségleteit kielégitő speciális tényezők jelenléte a döntỏ. A területi különbségekkel közvetlenül nem foglalkozik, a területi versenyben mindegyik régió sikeres lehet, ha megfelelő versenystratégiát dolgoz ki és hajt végre. A klasztereknél lényeges az adott régióban levő iparági bázis, döntési és ellenőrzési funkciók, emiatt ez a gondolatrendszer föleg a növekvő mérethozadékú és tudásközpont régiók versenyképességének leírására alkalmas.

Az evolucionista közgazdaságtan a hagyományos (mainstream) irányzatokkal szemben az innovációra és a tanulásra helyezi a hangsúlyt, és kiemeli a gazdasági struktúra folyamatosan növekvő változatosságát (Meyer 2003; Bajmócy 2007). Ebben az irányzatban a heterogenitás, a megkülönböztetés, a komplexitás és a bizonytalanság központi fogalmak (Martin et al 2003). A gazdasági növekedést mindezek értelmében nem determinisztikusan, de jelentősen befolyásolják a helyben meglévő feltételek és történelmi hăttér. Ezek a feltételek - föként az intézményi, társadalmi és technológiai feltételek - nem exogének, sőt, a „gazdasági evolúció" részei. Mindezek alapján a regionális versenyképesség a térség történelmi múltjában gyökerezik, azonban az új technológiák és új intézmények kiszoríthatják a régit, és a gazdasági növekedés új pályảját jelölhetik ki, mely az innováció következtében adott esetben a múlthoz alig kötödik. A hosszú távú regionális versenyképesség tehát a térségek azon képességétől függ, hogy tudnak-e újdonságot, innovációt generálni, amelyben a térbeli koncentráció fontos szerepet tölt be. 
Az evolucionista közgazdaságtanban a verseny központi fogalom, hiszen mindig létrejönnek újabb variációk, amelyek versengenek egymással, s amelyek közül bizonyos lehetőségek a verseny során szelektálódnak. A szelekciót nem csak a piac végezheti, azonban az alapmodellben jellemzöen a piac szelektál. Az evolucionista közgazdaságtan kiinduló feltevései és fogalmai kiválóan alkalmasak a regionális folyamatok tárgyalására, föleg a tudásközpont régiók esetében (Boschma-Martin 2007). Az innovatív magatartás régión belüli elterjedtségében és intenzitásában bekövetkező változások viszont döntően befolyásolhatják a területi különbségek alakulását. Az ilyen természetủ változások egy része létrejöhet spontán piaci folyamatok következtében is, így az evolucionista irányzat gondolatkörében a területi különbségek piaci automatizmusok és intézményi (közösségi) beavatkozások révén bekövetkező mérséklődése egyaránt értelmezhető. A területi különbségek ezen irányzat szerint szükségszerüek, de folyamatosan módosulnak is attól függően, hogy az adott régióban mennyire sikeres az innovációk generálása és fogadása. Az evolucionista alapfeltételek, innovációk és interaktív tanulás miatt ez az irányzat föleg a növekvő mérethozadékú és tudásközpont régiók versenyképességének leírására alkalmazható.

A fent részletezett irányzatok leírásából egyértelmüen kirajzolódik, hogy a területi verseny fogalmával kapcsolatba hozható elméleti közgazdaságtani irányzatok a regionális versenyképesség lényegének más-más aspektusait hangsúlyozzák. Hasonlóan az irányzatok kiinduló feltételeiből adódik, hogy a területi különbségeket hogyan értelmezik, mitől függ egy-egy régió fejlödése, a területi kiegyenlítődés automatikus-e, avagy a régióban születő döntésektől függ.

\section{Összegzés}

Tanulmányunkban arra vállalkoztunk, hogy a területi verseny, a regionális versenyképesség, valamint a területi különbségek fogalmát az elméleti közgazdaságtani irányzatok fogalomrendszerébe helyezzük, és megvizsgáljuk azok értelmezhetőségét, viselkedését, valamint kölcsönhatásait az egyes irányzatok fogalmi keretei között.

A regionális tudomány felfogása szerint a területi verseny fogalmára nem feltétlenül a hagyományos vállalati analógia (túlél/tönkremegy) a megfelelö. A vállalatok versenyénél sokkal jobban hasonlít a térségek versenye az egyéni sportversenyekhez (futás, kerékpározás, úszás stb.), ahol a legjobban teljesítő versenyzők győznek, de a többi versenyzöt - a győzelemről való lemaradás lelki fájdalmain kívül - semmilyen hátrány nem éri, ủjra indulhatnak a következö versenyben. Tehát létezik területi verseny, de - elfogadva Krugman érvelését - annak jellemzői alapvetően eltérnek a vállalatok közötti piaci versenytől. Mivel területi egységek viszonylatában is értelmezhetö egyféle speciális verseny, ebböl kifolyólag van értelme a területi versenyképesség fogalmát definiálni.

Lényeges, hogy a bemutatott közgazdaságtani irányzatok a fejlödést vagy a növekedést írják le elsősorban, lényegében a termelékenység térbeliségének alakulását elemzik. Többségük nem foglalkozik azonban a versenyképesség fejlesztési („ké- 
pesség") oldalával, azaz a gazdaságpolitikai, gazdaságfejlesztési kérdésekkel, holott felfogásunk szerint az is a regionális versenyképesség szerves részét képezi.

Az elméleti közgazdaságtani irányzatok áttekintéséből az is kitủnik, hogy az egyes elméletek több lényegi kérdésben is ellentmondanak egymásnak, így a regionális versenyképesség fogalmával kapcsolatos konzisztens elmélet általános szintézissel nem hozható létre. Ugyanakkor mindegyik elmélet külön-külön hangsúlyoz egy-egy folyamatot, tényezőt vagy részelemet, melyek egyenként a regionális versenyképesség fogalmának egy-egy fontos szeletét képezik. Ebböl következöen ezen megközelítések egyes részei egymást kiegészitve segítenek hozzá a regionális versenyképesség fogalmának pontosabb megértéséhez. A különféle elméleti irányzatok tehát nem elkülönült variánsként értelmezendők a regionális versenyképesség fogalmának pontosítására tett erőfeszítések során, hanem az eltéró irányzatok ugyanazon probléma más-más vetületét emelik ki, így eredményeik többségét érdemes átgondolni és összeilleszteni.

Az alapján, hogy - a bevezetésben említetteknek megfelelően - a piaci automatizmusok képesek-e a területi különbségek mérséklésére, az elméleti közgazdaságtani irányzatok egyfajta tipizálása adható meg. A klasszikus és a neoklasszikus közgazdasági elmélet közismerten a piac és a "láthatatlan kéz" mellett érvel, elveti mindenféle külső beavatkozás (így a regionális politika) eszköztárának gazdasági folyamatokba való integrálását. Ezzel szemben Keynes és az idóben ôt követő elméleti közgazdaságtani irányzatok lehetőséget nyújtanak arra, hogy az adott irányzatokat a külső beavatkozás, vagyis a versenyképesség javítására tett erőfeszítések oldaláról vizsgáljuk.

Mindezeket a komparatív és kompetitív elönyök elméletével összevetve elmondható, hogy a területi különbségek mérséklódése automatikus abban az esetben, ha a gazdaságot a komparatív elönyök mozgatják, ekkor nincs területi verseny, következésképpen nincs értelme versenyképességröl sem beszélni. Abban az esetben pedig, amikor a gazdaságot kompetitiv előnyök mozgatják, akkor a piaci automatizmusok nem vezetnek a területi különbségek mérsékléséhez, ilyenkor szükséges a külső beavatkozás, és van értelme versenyről, valamint versenyképességröl is beszélni.

\section{Jegyzetek}

${ }^{1}$ Agglomerációs előnyök alatt a regionális tudományban általában a gazdasági tevékenységek térbeli sürüsödéséből származó elönyöket értjük. Az agglomerációs elönyök alaptípusai: nagyvállalati, lokalizációs és urbanizációs előnyök (Lengyel-Rechnitzer 2004).

${ }^{2}$ Az X-hatékonyság „olyan szituáció, amikor a cég összköltségét nem minimalizálják, mivel az adott inputokból származó tényleges output kisebb a maximálisan megvalósitható szintnél. Az Xhatékonyság a monopólium, illetve a piaci erö közvetlen függvénye, amikor a kompetit́v nyomások gyengülnek." (Pearce 1993, 594). Dinamikus megközelítésben: az X-hatékonyság nővekedése során a piaci versenykörnyezet nagyobb termelékenység elérésére ösztönzi a gazdasági szereplöket (Gáspár 2004).

3

Urbanizációs előnyök (urbanization economies of scale), másképpen urbanizációból eredő méretgazdaságosság: külsők az iparág és belsők a térség (város) szempontjából, általában több iparág/üzletág vállalatai koncentrálódnak, a nagy piac miatt sokféle gazdasági tevékenység, például a megosztható üzleti szolgáltatások többsége gazdaságosan végezhető (a nagyvárosokra jellemző elönyök). Az urbanizációs 
Fenyővári Zsolt - Lukovics Miklós :

A regionális versenyképesség és a területi különbségek kölcsönhatásai.

Tér és Társadalom 22. évf. 2008/2. 1-20. p.

elönyök föleg a város méretéből, lakosságszámából, a városi területeken koncentrált különböző gazdasági tevékenységek egymásra hatásából eredö költségmegtakaritások.

${ }^{4}$ Lokalizációs előnyök (localization economies of scale), másképpen lokalizációból eredỏ méretgazdaságosság: külsők egy vállalat és belsők az iparág számára, azaz egyetlen iparághoz/üzletághoz tartozó vállalatok térbeli súrüsöđéséről van szó. A lokalizációs előnyök főleg kis- és középvárosokban figyelhetök meg, és akkor keletkeznek, amikor egy adott iparág vállalatainak földrajzi koncentrálódása és a köztük levő kapcsolatok mérhető hasznot hoznak, a fellépő specializáció miatt javul a termelékenységük, illetve az azonos iparághoz tartozó cégek hasonló inputjaikat (a megosztható iparági szolgáltatásokat: könyvelés, jogi tanácsadás stb.) alacsonyabb egységköltségen tudják beszerezni.

${ }^{5}$ A területi verseny ,egy olyan folyamat, amely a területi egységek között zajlik és célja a régióban, városban élők jólétének növelése a regionális, helyi gazdaság fejlődésének elősegítésével, amely fejlödést bizonyos csoportok a helyi politikákon keresztül más térségekkel versengve, rivalizálva próbálnak befolyásolni explicit vagy gyakran implicit módon." (Lengyel 2003, 152)

${ }^{6}$ Annak ellenére, hogy a regionális versenyképesség fogalma a fentiek miatt nem tárgyalható a neoklaszszikus elméleti háttér keretei között, mégis a neoklasszikus közgazdaságtan egyik elméleti kategóriája, az extern hatás fogalma a versenyképességi elemzésekben és napjaink területi különbségeinek elemzésekor kiemelt fontossággal bír. „A külső gazdaságosság [...] célja az elemzésbe bevonni a gazdasági tevékenységek nem szándékolt, nem ellentételezett olyan mellékhatásait, olyan lényeges tényezöit, amelyek az árakkal (költségekkel) kifejezhetö piaci tranzakciókon kiviül esnek, föleg amiatt, hogy az eröforrás-allokáció hatékonyabbá váljon." (Lengyel-Mozsár 2002, 10)

${ }^{7}$ A 2003-as Európai Versenyképességi Jelentés az agglomerációt, a specializációt és a növekvő skálahozadékot emeli ki, mint a regionális versenyképességgel szoros kapcsolatba hozható térgazdasági alapfogalmakat (EC 2003).

${ }^{8}$ Douglas North (2005) szerint a tranzakciós költségek (vagyis a „neoklasszikus” költségfüggvények segítségével leírható költségeken túlmutató, de a különbőző gazdasági rendszerek hatékony mủködéséhez nélkülözhetetlen egyéb költségek) részaránya a gazdaság mủködésének összes költségén belül meghaladja az 50\%-ot. Jelentőségük tehát - enyhén szólva - nem elhanyagolható.

\section{Irodalom}

Ács J.Z.-Varga A. (2000) Térbeliség, endogén növekedés és innováció. - Tér és Társadalom. 4. 23-38. o.

Bajmócy Z. (2007) A technológiai inkubáció elmélete és alkalmazási lehetóségei hazánk elmaradott térségeiben. Doktori értekezés. Szegedi Tudományegyetem Gazdaságtudományi Kar, Szeged.

Benko, G. (1999) Regionális tudomány. Dialóg Campus, Budapest-Pécs.

Boschma, R.-A.-Martin, R. (2007) Constructing an evolutionary economic geography. - Journal of Economic Geography. 7. 537-548. o.

Budd, L.-Hirmis, A.K. (2004) Conceptual Framework for Regional Competitiveness. - Regional Studies. 9. 1015-1028. o.

Camagni, R. (2002) On the Concept of Territorial Competitiveness: Sound or Misleading? - Urban Studies. 13. 2395-2411. o.

Coase, R.H. (2005) The Institutional Structure of Production. - Menard, C.-Shirley, M.M. (eds.) Handbook of New Institutional Economics. Springer, Dordrecht. 31-40. o.

EC (1997) Treaty of Amsterdam Amending the Treaty on European Union, the Treaties Establishing the European Communities and Related Acts. Official Journal C 340, Luxembourg.

EC (1999) Sixth Periodic Report on the Social and Economic Situation and Development of Regions in the European Union. European Commission, Luxembourg.

EC (2003) European Competitiveness Report 2003. European Commission, Brussels.

EC (2006) A Tanács határozata (2006. október 6.) a kohézióra vonatkozó közösségi stratégiai iránymutatásokról (2006/702/EK). Official Journal. L 291/11, Luxembourg.

EC (2007) The Growth and Jobs Strategy and the Reform of European Cohesion Policy. Fourth Progress Report on Cohesion. European Commission, Brussels.

Enyedi Gy. (1996) Regionális folyamatok Magyarországon az átmenet idószakában. Hilscher Rezső Szociálpolitikai Egyesület, Budapest.

Gardiner, B.-Martin, R.-Tyler, P. (2004) Competitiveness, Productivity and Economic Growth across the European Regions. - Regional Studies. 9. 1045-1067. o. 
Fenyővári Zsolt - Lukovics Miklós :

A regionális versenyképesség és a területi különbségek kölcsönhatásai.

Tér és Társadalom 22. évf. 2008/2. 1-20. p.

TÉT XXII. évf. 2008 m 2

A regionális versenyképesség és a ...

Gáspár P. (2004) Kereskedelempolitika. - Veress J. (szerk.) Fejezetek a gazdaságpolitikából. AULA, Budapest. 84-98. o.

Horváth Gy. (szerk.) (2006) Régiók és települések versenyképessége. MTA RKK, Pécs.

Krugman, P. (1994) Competitiveness: A dangerous obsession. - Foreign Affairs. 2. 28-44. o.

Krugman, P. (2000) A földrajz szerepe a fejlődésben. - Tér és Társadalom. 4. 1-28. o.

Krugman, P.-Obstfeld, M. (2003) Nemzetközi gazdaságtan. Panem Kiadó, Budapest.

Lengyel I. (2003) Verseny és terülleti fejlödés: térségek versenyképessége Magyarországon. JATEPress, Szeged.

Lengyel I.-Mozsár F. (2002) A külső gazdasági hatások (externáliák) térbelisége. - Tér és Társadalom. 2. $1-20.0$.

Lengyel I.-Rechnitzer J. (2004) Regionális gazdaságtan. Dialóg Campus, Budapest-Pécs.

Lucas, R.E. (1988) Ont he Mechanics of Economic Development. - Journal of Monetary Economics. 22. 3-42. 0 .

Martin, R.L. et al (2003) A Study on the Factors of Regional Competitiveness. A final report for The European Commission DG Regional Policy. University of Cambridge, Cambridge.

Mátyás A. (1993) A modern közgazdaságtan története. Aula, Budapest.

Mátyás A. (1996) A hagyományos közgazdaságtan bírálata és kutatási körének kiszélesítése az ủj intézményi iskola képviselôi részéről. - Közgazdasági Szemle. 7-8. 614-628. o.

Mátyás A. (2002) A korai közgazdaságtan története. Aula, Budapest.

Meyer D. (2003) Evolúciós közgazdaságtan elmélettörténeti szemszögböl vagy közgazdasági elmélettörténet evolúciós szemszögböl. - Bekker Zsuzsa (szerk.) Tantörténet és közgazdaságtudomány. AULA, Budapest. 295-312. 0.

Nemes Nagy J. (2001) A területi versenyképesség: elöképek, elemzési módszerek és kistérségi teszt. Kézirat. ELTE Regionális Földrajzi Tanszék, Budapest.

Nemes Nagy J. (2005) Fordulatra várva - a regionális egyenlötlenségek hullámai. - Dövényi Z.Schweizer F. (szerk.) A földrajz dimenziói. MTA FKI, Budapest. 141-158. o.

North, D.C. (2005) Institutions and the Performance of Economies over Time. - Menard, C.-Shirley, M.M. (eds.) Handbook of New Institutional Economics. Springer, Dordrecht. 21-30. o.

Pearce, D.W. (1993) A modern közgazdaságtan ismerettára. Közgazdasági és Jogi Könyvkiadó, Budapest.

Pejovich, S. (1992) A tulajdonjogok közgazdaságtana. KJK, Budapest.

Porter, M.E. (1998) On Competition. The Free Press, New York.

Porter, M.E. (2006) The Business Competitiveness Index (BCD) ranking. - Global Competitiveness Report 2006-2007. World Economic Forum, Geneva.

Ricardo, D. (1940) A közgazdaság és adózás alapelvei. Magyar Közgazdasági Társaság, Budapest.

Romer, P. (1990) Endogenous Technological Change. - Journal of Political Economy. 98. 71-102. o.

Samuelson, P.A.-Nordhaus, W.D. (2000) Közgazdaságtan. KJK-KERSZÖV, Budapest.

Schumann, J. (1998) A mikroökonómiai elmélet alapvonásai. JATEPress, Szeged.

Szentes T. (2005) Fejlödés, Versenyképesség, Globalizáció I. Akadémiai Kiadó, Budapest.

Tötdling, F.-Trippl, M. (2005) One size fits all? Towards a differentiated regional innovation policy approach. - Research Policy. 1203-1219. o.

Török Á. (1999) Verseny a versenyképességért. MeH Integrációs Stratégiai Munkacsoport, Budapest.

Valentinyi Á. (1995) Endogén növekedéselmélet. Áttekintés. - Közgazdasági Szemle. 6. 582-594. o.

Varga A. (2003) Thünen és az „Új Gazdaságföldrajz” térgazdaságtana. - Barancsuk J. (szerk.) Tanulmányok Zinhober Ferenc Professzor emlékére. Pécsi Egyetemi Könyvkiadó, Pécs. 85-98. o.

Williamson, O.E. (2005) Transaction Cost Ecomomics. - Menard, C.-Shirley, M.M. (eds.) Handbook of New Institutional Economics. Springer, Dordrecht. 2I-30. o. 


\section{INTERACTIONS BETWEEN REGIONAL COMPETITIVENESS AND TERRITORIAL DISPARITIES}

\section{ZSOLT FENYŐVÁRI - MIKLÓS LUKOVICS}

The goal of this study is to review and synthesize the different views of the main economic schools in connection with mitigation of regional disparities, spatial competition, regional competitiveness and theoretical region types. Based on different economic premises different hypotheses will be formulated and also different conclusions will accordingly be arrived at within regional science about how to create cohesion between regions subject to different conditions and of various state of development. We believe that even though we get different results based on different theoretical economic backgrounds and models, due to the interdisciplinary character of regional science, this will not question the adequacy of our science, but rather it draws attention to its being multi-faceted and problem-sensitive. 